\title{
Examination of Talent Selection Methods in Different Sports Branches
}

\author{
Ömer Kaynar ${ }^{1}$, Fatih Bilici ${ }^{1}$ \\ ${ }^{1}$ Muş Alparslan University, School of Physical Education and Sports,, Department of Physical Education and Sports \\ Education, Turkey \\ Correspondence: Ömer Kaynar, School of Physical Education and Sports, Department of Physical Education and Sports \\ Education Muş, Turkey. Email: o.kaynar@alparslan.edu.tr
}

\author{
Received: November 28, 2018 \\ Accepted: December 31, 2018 Online Published: January 1, 2019 \\ doi:10.11114/jets.v6i12a.3925 \\ URL: https://doi.org/10.11114/jets.v6i12a.3925
}

\begin{abstract}
The purpose of this study was to determine the talent selection methods applied to athletes involved in different sports branches in Turkey. The research population consisted of 724 volunteer athletes who were active in sports clubs in thirty seven different cities of Turkey. Semi-structured interview form was used as data collection tool. It was determined that no talent test was applied to $512(70.72 \%)$ of 724 athletes who participated in the study and $212(29.28 \%)$ were put to talent test methods by their coaches. Of 212 athletes who were put to talent test, 41 (5.66\%) were observed for their physical characteristics, $59(8.14 \%)$ for their competitions, $75(10.35 \%)$ for their basic motor skills (speed, strength, endurance, coordination, balance, flexibility and agility) and $37(5.11 \%)$ for their technical capacities in competitions. As a result; it is estimated that the application of physical, mental, physiological, body composition and genetic tests all together while determining the talent selection in sports will be the most effective method to detect talented athletes.
\end{abstract}

Keywords: sports, talent selection, different sports branches, talent test methods

\section{Introduction}

Talent selection plays a significant role in identifying talented athletes. The talent of an individual in sports brings success. For this reason, many developed countries such as England, China, Russia, Germany and particularly the USA used talent selection methods in order to direct the candidates of promising athletes to the sports branches they are capable of (Mirwald, Baxter-Jones, Bailey \& Beunen (2002).; Ba1ley, 2010).

In addition, the athlete is likely to be successful if his physical, physiological and anatomical structure is inclined to the given sports branch (Ayan \& Mülazımoğlu, 2010). Therefore, talent selection methods play a key role in determining talented athletes.

The concept of talent is defined as "a person's ability to understand or do something, capability and aptitude" in Turkish Language Institution. The concept of talent in sports, however, can be defined as all of the genetic factors, innate physical and physiological capacities, mental skills and high-performance characteristics that are believed to be effective to be successful in sports. (Kaynar \& Bilici, 2017).

Talent selection in sports science mainly consists of two methods. These are natural selection and scientific selection (Bompa, 2003). Natural selection can be defined as the random sports branch selection of a person who is directed to sports by trainer, family or teacher without being put to any talent test or scientific test. Scientific selection, on the other hand, can be defined as directing athlete candidate to a certain sports branch according to the results of the test conducted in the light of scientific data and applied by the experts to identify the talented athlete candidates. In the literature, there are a good number of studies conducted on talent selection methods which are applied to determine talented athlete candidates. Some of these studies emphasize that physical, physiological and motoric features are effective in directing individuals to sports (Hekim, Tokgöz, Reyhan \& Y1ldırım, 2012; Milanese, Bortolamı, Bertucco \& Verlato, 2010). Others report that genetic factors and muscular, anthropometric and psychological characteristics are effective in identifying talented athletes (Ayan, 2010; Eynon, Ruiz, Oliveira, Duarte \& Birk, 2011).

There is no research which investigates talent test methods used to detect talented athletes in different sports branches in Turkey. However, the methods used in talent tests in all sports branches are very important in identifying the athletes who may be successful and directing them to the related sports branch. Therefore, this study aims to determine the talent selection methods applied to athletes engaged in different sports branches in Turkey. 


\section{Methods}

\subsection{Participants}

The research population consisted of 724 volunteer athletes from different branches; wrestling (150), football (92), volleyball (80), handball (71), taekwondo (68), basketball (55) table tennis (53), athletics (32), badminton (36), tennis (22), judo (14), karate (18), skiing (11), fencing (7) and gymnastics (6), boxing (6), field hockey (3) in 37 different cities of Turkey. The convenience sampling method was used to detect the participants with the purpose of easy access to the participantation, improving reliability and saving time and money.

\subsection{Data Analysis}

Semi-structured interview technique was used in this study which is conducted based on the qualitative data collection technique. Semi-structured interview form developed by the researchers was used as data collection tool in the study. In order to obtain comparative results, the semi-structured interview form, which was preferred in written, was developed to determine the talent test of the athletes. In the interview form, there are questions such as "education background, starting age of sports, active sports years, best sports grade, whether or not talent tests are applied, what methods are used, if any". Before starting the interviews with the athletes, the preliminary application was carried out and the interview form was finalized after necessary modifications were made according to the recommendations of the experts. In the preparation of the interview questions developed by the experts; attention was paid to ensure that the questions are clear, understandable and easy to answer and they are not complicated or guiding (Y1lmaz \& Altınkurt, 2011). The athletes were informed about the content of the interview form and the written interview form was applied. The written interview form applied to the athletes was transformed into the computer and the data were recorded. The frequency ranges and percentages of the data recorded on the computer were calculated and the data were interpreted. While interpreting the data, generally frequency and percentages are used. Tables are formed by determining the appropriate themes, the most and the least common answers are interpreted and the research findings are interpreted and evaluated (Büyüköztürk, Çakmak, Akgün \& Karadeniz, 2011).

\section{Results}

Education background, best sports grade, starting age of sports and active sports years of the athletes are presented in Table 1.

Table 1. Education background, best sports grade, starting age of sports and active sports years of the athletes

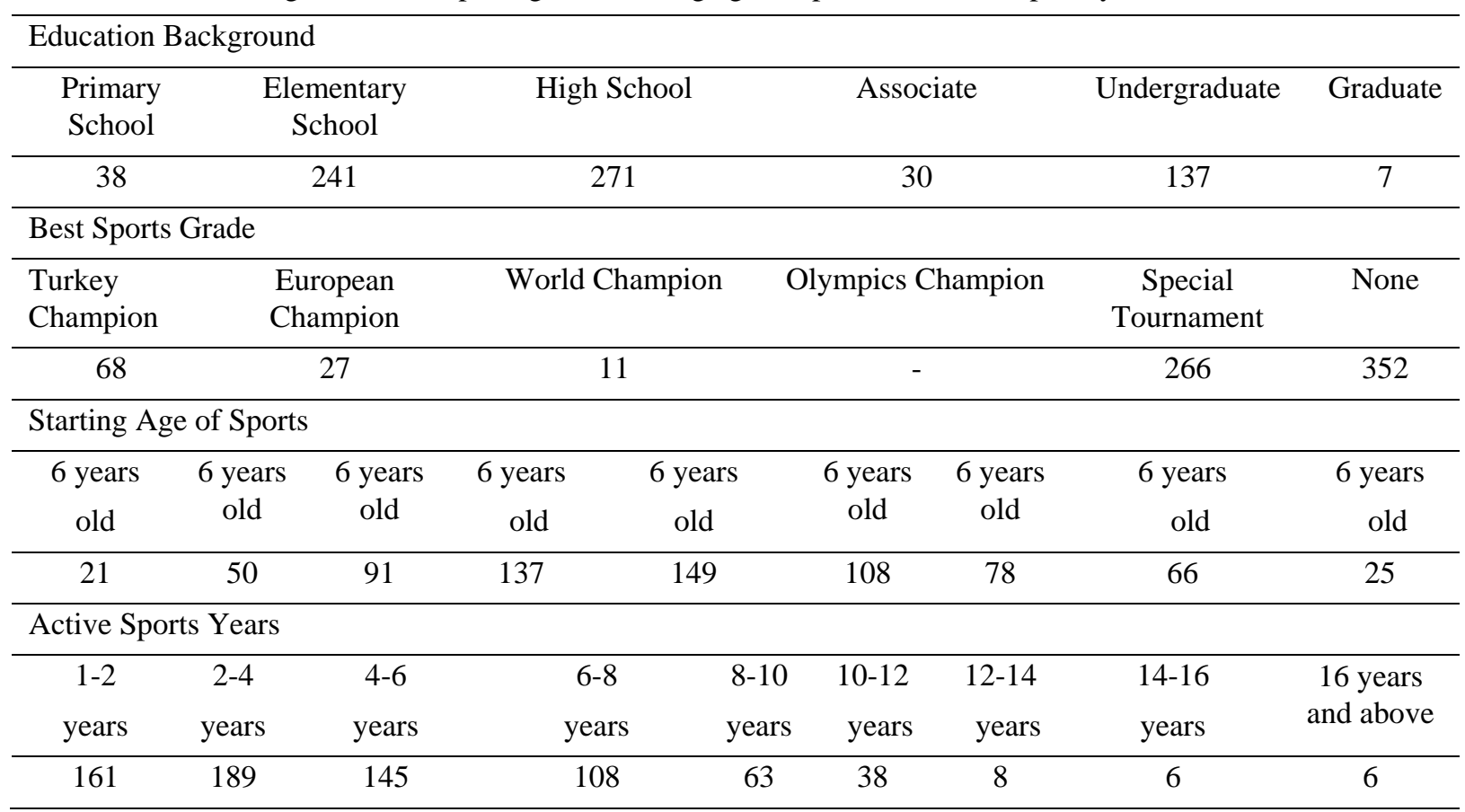

As table 1 shows the participants of the study are 724 athletes engaged in different sports branches with the mean age of 16.59 height $(\mathrm{cm})$ of 171.05 and mean weight $(\mathrm{kg})$ of 68.27 . 
Table 2. Talent test applications

Talent Test $(\mathrm{n} / \%)$

\begin{tabular}{lccc}
\hline Yes $(\mathrm{n} / \%)$ & No $(\mathrm{n} / \%)$ & \\
\hline $212 / 29.28$ & $512 / 70,72$ & \\
\hline Talent Test Methods $(\mathrm{n} / \%)$ & & Basic motoric features & $\begin{array}{c}\text { Technical capacity in the } \\
\text { competition }\end{array}$ \\
\hline Physical features & $\begin{array}{c}\text { Observing the } \\
\text { competition }\end{array}$ & $75(10.35)$ & $37(5.11)$
\end{tabular}

It was found that $512(70.72 \%)$ of the 724 athletes who participated in the study were not put to any talent tests and 212 (29.28\%) of them were put to talent test methods by their coaches. Of the 212 athletes who were put to talent test methods, $41(5.66 \%)$ were observed for their physical characteristics, 59 (8.14\%) for their competitions, $75(10.35 \%)$ for their basic motor skills (speed, strength, endurance, coordination, balance, flexibility and agility) and $37(5.11 \%$ ) for their technical capacity in the competitions Table 2.

\section{Conclusions and Recommendations}

Physical and motoric features, genetic structure, somatotype characteristics, body composition, mental ability, technique, tactics, and experience have an important role in the success of talented athletes (Gökdemir \& Koç, 2000; Demiral, Erdemir \& Kizılyaprak 2001; Eniseler, 2010). In addition, many literature studies report that talent test methods used in the identification of talented athletes are an important criterion in determining talented athletes (Ayan, 2010; Küçük, 2009).

It was determined that $512(70.72 \%)$ of the 724 athletes who participated in the study were not put to any talent test and $212(29.28 \%)$ were put to talent test methods by their coaches. It was also determined that of the 212 athletes who were put to talent test methods, $41(5.66 \%)$ were observed for their physical characteristics, $59(8.14 \%)$ for their competitions, $75(10.35 \%)$ for their basic motor skills (speed, strength, endurance, coordination, balance, flexibility and agility) and $37(5.11 \%)$ for their technical capacity in the competitions.

In the study conducted to detect elite female judoists, body composition, long jump with pause, static and dynamic balance, coordination, quickness and speed tests were used (Mülazımoğlu, 2009). For the identification of the talent of 91 new basketball players, methods of throwing the ball to the hoop, throwing the ball to the hoop by skimming, dribbling, dribbling, bringing the pins down, throwing the ball to the target on the wall and fast pass on the wall were applied. In another study, wrestling competitions, $800 \mathrm{~m}$ running test, $30 \mathrm{~m}$ running test, flexibility and mental skill tests were performed on the wrestlers to be accepted in wrestling training centre (Özal, 2003).

In many sports branches, somatotype characteristics, body composition, muscle mass, and body fat ratio may affect sportive performance positively or adversely (Kerr, Ackland \& Schreiner 1995; Kürkçü, Hazar \& Özdăg 2009; Eler 2018).

In talent selection, the trainer's observation and the decisions of the experts are decisive (Kozel, 1996). In the study conducted on basketball players, it was emphasized that technical characteristics play an important role in success (Kılınç, Erol \& Kumartaşl1, 2011).

Literature findings and results of the present study also indicate that similar physical, physiological and anthropometric test methods are applied to the athletes engaged in different sports branches.

It is known that genetic characteristics have an effect on the physical, physiological and anthropometric features of the individual. Therefore, genetic studies in sports conducted in recent years aim to determine talented athletes and maximize the sportive performance (Epstein, 2013; Sercan et.al. 2014; Alonso et.al., 2014).

It has been reported that the genetic feature clearly determines to which aerobic and anaerobic performance a person is inclined and how long he will respond to training (Bouchard, Taylor, Simaneau \& Dulac, 1991). In the study conducted with 14 pairs of identical twins, it was found that approximately $48 \%$ of the lactic anaerobic capacity was determined by the factors passing by the genetics in the high-intensity training (Simoneau et al., 1986).

It is known that the effect of exercise on the heart is controlled by genes and exercise has different levels of effect on heart and heart functions of athletes with different genes (Ulucan, Göle, Altindas \& Güney2013). It has been reported that genetic factors affect the physiological characteristics such as VO2max capacity, strength, endurance, types of muscle fibers, heart size, and lactate (Mustafina et al. 2014).

Many performance parameters such as physical, mental, physiological, anthropometric and somatotype body 
composition have been used to determine talented athlete for talent selection. Although genetic studies are known to be an important criterion in talent selection, they are not much applied in infrastructure studies.

It is probable that more dramatic results will be obtained on condition that genetic studies are included in the performance parameters used in the identification of talented athletes in sports. Because genetic studies ensure directing individuals to certain sports branch or within a sports branch based on their physical, physiological and anatomical tendencies; and help prepare individual training and nutrition programs particularly in individual sports and assess the disability risk.

As a result; while determining the talent selection in sports, it is predicted that the application of the physical, mental, physiological, body composition and genetic tests all together will be the most effective method to detect the talented athlete.

\section{References}

Alonso, L., Souza, E., Oliveira, M., Nascimento, L., \& Dantas, P. (2014). Heritability of aerobic power of individuals in northeast Brazil, Biol. Sport 31, 267-270. https://doi.org/10.5604/20831862.1120933

Ayan, V., \& Mülazımoğlu, O. (2010). Selection of talent in sports and directing the physical characteristics and some performance profiles of girls aged 8iller10 years (Ankara case). Nigde University Journal of Physical Education and Sport Sciences, 4(3), 152-159.

Barley, D. A. (1997). The Saskatchewan pediatric bone mineral accrual study: bone mineral acquisition during the growing years. Int. J. Sports Med. 18, S191-S194. https://doi.org/10.1055/s-2007-972713

Bompa, T. O. (2003). Training theory and method, Ankara: Bağırgan Publishing.

Bompa, T. O. (2003). Training theory and method, Ankara: Bağırgan Publishing.

Bouchard, C., Taylor, A. W., Simaneau, J., Dulac, S. Testing Anaerobic Power and Capacity. L MacDouall, H. A.

Büyüköztürk, Ş., Çakmak E. K., Akgün, Ö. E., Karadeniz, Ş., \& Demirel, F. (2011). Scientific research methods, PegemA publishing, 8th edition, Ankara. https://oguzcetin.gen.tr/bilimsel-arastirma-yontemleri.html

Demiral, Ş., Erdemir, İ., \& Kizllyaprak., A. H. (2011). Ability selection in female judoists. USAD, 3(1), 29-31. http://www.acarindex.com/uluslararasi-spor-arastirmalari-dergisi/bayan-judocularda-yetenek-secimi-28743

Eler, N. (2018). Examination of the anthropometric and physical fitness parameters in different sports. Journal of Physical Education and Sports Science, 20, 31-45. http://dergipark.gov.tr/download/article-file/553478.

Eniseler, N. (2010). Football practice in the light of science. 1. Printing. İzmir: United Printing. https://www.nadirkitap.com/bilimin-isiginda-futbol-antrenmani-niyazi-eniseler-kitap3398230

Epstein, D. (2013). The Sports Gene. Inside the Science of extraordinary Athlethic Performance. The gene-Free Model of Expertise, Penguin Group New York. https://www.amazon.com/Sports-Gene-Extraordinary-Athletic Performance/dp/161723012X

Eynon, N., Ruiz, J. R., Oliveira, J., Duarte, J. A., Birk, R., \& Lucia, A. (2011). Genes and elite athletes: A road map for future research. J. Physiol., 598, 3063-3070. https://doi.org/10.1113/jphysiol.2011.207035

Gökdemir, K., \& Koç, H. (2000) Evaluation of Some Physiological Parameters of High Level Handballer and Volleyball Female Athletes. Dumlupinar University Journal of Social Sciences, 1(4), 259-262. http://dergiler.ankara.edu.tr/dergiler/17/886/11150.

Hekim, M., Tokgöz, M., Reyhan, S., \& Yıldırım, Y. (2012). To Compare Some Motoric Features of 12-14 Age Group Girl Children Making Sport And Don't Make Sport. SSTB International Refereed Academic Journal of Sports, 2(3), 31-38.

Kaynar, Ö., \& Bilici, M. F. (2017). Analysis of the Talent Selection in Turkish Wrestling. International Journal o Science Culture and Sport, 5(4), 347-355. https://doi.org/10.14486/IntJSCS698

Kerr, D. A., Ackland, T. R., \& Schreiner, A. B. (1995). The Elite Athlete-Assessing Body Shape, Size, Proportion and Composition, Asia Pacific J ClinNutr, 4, 25-29.

Kılınç, F., Erol A. E., \& Kumartaşl1, M. (2011). The effect of combined technical trainings on some physical, force and technical properties in basketball infrastructure, International Journal of Human Sciences, 8(1), 220. http://www.insanbilimleri.com.

Kozel J. (1996) Talent identification and development in Germany.Coaching Focus, 31, 5-6. https://pdfs.semanticscholar.org/1be2/9602d23a36cb08f75732e54b5506b2b63182. 
Küçük, V. (2009). Futbolda yetenek seçimi. Turkey Football Federation of Football Training Publications, İstanbul. http://dergipark.gov.tr/download/article-file/290170.

Kürkçü, R., Hazar, F., \& Özdağ, S. (2009). A Study on Body Composition, Body Components and Somatotype Properties of Soccer Players. Nigde University Journal of Physical Education and Sports Sciences, 3(2), 113-119. dergi.nigde.edu.tr/index.php/besyodergi/article/view/108/95

Milanese, C., Bortolam1, O., Bertucco, M., Verlato, G., \& Zancarano, C. (2010). Anthropometry And Motor Fitness in Children Aged 6-12 Years. Journal of Human Sport \& Exercise, 5(2), 265-279. https://doi.org/10.4100/jhse.2010.52.14

Mirwald, R. L., Baxter-Jones, A. D. G., Bailey, D. A., \& Beunen G. P. (2002). An assessment of maturity from anthropometric measurements. Medicine and Science in Sports and Exercise, 34(4), 689-694. https://www.researchgate.net/publication/11432300

Mülazımoğlu, O, Vedat, A., \& Mülazımoğlu, E. D. (2009). Validity and Reliability Study of Basketball Talent Test Battery. Nigde University Journal of Physical Education and Sports Sciences, 3(1), 23-26. dergi.nigde.edu.tr/index.php/besyodergi/article/view/79/63.

Mustafina, L. J., Naumov, V. A., Cieszczyk, P., Popov, D. V., Lyubaeva, E. V., Kostryukova E. S., et al. (2014). AGTR2 gene polymorphism is associated with muscle fibre composition, athletic status and aerobic performance. Exp. Physiol, 99, 1042-1052. https://doi.org/10.1113/expphysiol.2014.079335

Özal, M., Gökdemir, K., Arslan, C., \& Orhan, S. (2003). A Research on Tests Applied to Wrestling Training Centers for Skilled Athlete Selection Exams. Gazi Journal of Physical Education and Sport Sciences (Gazi BESBD), VIII(2), $19-32$.

Sercan, C., Eken, B. F., Erel, Ş., Ülgüt, D., Kapıcı, S., \& Ulucan, K. (2014). Sport Genetics and Ace Gene Relationship. Inonu University, Journal of Physical Education and Sport Sciences, 2016, 3(2), 26-34. http://dergipark.gov.tr/download/article-file/292190.

Simoneau, J. A., Lortie, G., Boulay, M. R., Marcotte, M., Thibault, M. C., \& Bouchard, C. (1986). Inheritance of human skeletal muscle and anaerobic capacity adaption to high intensity intermittent training. International Journal of Sports Medicine, 7, 167-171. https://doi.org/10.1055/s-2008-1025756

Ulucan, K., Göle, S., Altindas, N., \& Güney, A. (2013). Preliminary findings of alphaactinin-3 gene distribution in Turkish elite wind surfers. Balkan journal of medical genetics, 16(1), 69-72. https://doi.org/10.2478/bjmg-2013-0020

Wenger, H Gren Ed.) (1991). Physiological Testing of the High Performance Athlete. Champaign, IL: Human Kinetics Books. 175-221. https://www.amazon.com/Physiological-Testing-High-Performance-Athlete/dp/0873223004

Yılmaz, K., \& Altınkurt, Y. (2011). The opinions of the Private Teachers who work for the new course on their working conditions in their institutions. Educational Sciences in Theory and Practice, 11(2), 635-650.

\section{Copyrights}

Copyright for this article is retained by the author(s), with first publication rights granted to the journal.

This is an open-access article distributed under the terms and conditions of the Creative Commons Attribution license which permits unrestricted use, distribution, and reproduction in any medium, provided the original work is properly cited. 